\title{
Author Correction: Microbiome differential abundance methods produce different results across 38 datasets
}

Jacob T. Nearing (1), Gavin M. Douglas, Molly G. Hayes (1), Jocelyn MacDonald, Dhwani K. Desai, Nicole Allward, Casey M. A. Jones, Robyn J. Wright, Akhilesh S. Dhanani (D, André M. Comeau (D) \& Morgan G. I. Langille

Correction to: Nature Communications https://doi.org/10.1038/s41467-022-28034-z, published online 17 January 2022.

In the original version of this Article, the reference "Turnbaugh, P. J. et al. A core gut microbiome in obese and lean twins. Nature 457, 480-484 (2009)" was duplicated labelled as 59 and 80 in the Reference section. The duplicate reference has now been deleted and the following references 81,82 , and 83 have been changed to 80,81 , and 82 , respectively. In addition, the relevant citations in the text have been corrected. These have been corrected in both the PDF and HTML versions of the Article.

Published online: 03 February 2022

\footnotetext{
(c) (i) Open Access This article is licensed under a Creative Commons Attribution 4.0 International License, which permits use, sharing, adaptation, distribution and reproduction in any medium or format, as long as you give appropriate credit to the original author(s) and the source, provide a link to the Creative Commons license, and indicate if changes were made. The images or other third party material in this article are included in the article's Creative Commons license, unless indicated otherwise in a credit line to the material. If material is not included in the article's Creative Commons license and your intended use is not permitted by statutory regulation or exceeds the permitted use, you will need to obtain permission directly from the copyright holder. To view a copy of this license, visit http://creativecommons.org/licenses/by/4.0/.
}

() The Author(s) 2022 